\title{
Konsep Dasar, Proses dan Ruang Lingkup Administrasi Pendidikan
}

\author{
Melia Sri Devi1, hade afriansyah2 \\ 1Universitas Negeri Padang, Padang, Indonesia (meliasridevi@gmail.com) \\ 2Universitas Negeri Padang, Padang, Indonesia, (hadeafriansyah@fip.unp.ac.id)
}

\section{A. Konsep dasar Administrasi \\ Pendidikan(pengertian, pentingnya dan tujuan)}

\section{Pengertian administrasi pendidikan}

Sondang Siagian, dalam (Kamars, 2004) berpendapat bahwa proses keseluruhan kerjasama antara dua orang atau lebih yang atas rasionalitas tertentu untuk mencapai tujuan yang telah ditentukan sebelumnya.

Harus diakui bahwa di kalangan ilmuwan administrasi/manajemen dan di kalangan banyak praktisi di Indonesia istilah administrasi masih dalam polemic,istilah sehari- hari administrasi sebagai clerical work dan kesan bergengsi dalam penggunaan

istilah manajemen (Engkoswara, 2011). Administrasi berasal dari bahasa latin Administrare yang artinya membantu atau melayani. Dalam bahasa inggris perkataan administrasi berasal dari kata administration, yang memiliki arti melayani atau mengelola suatu organisasi dalam mencapai tujuannya secara intensif (Hadjaya, 2012)

Dalam jurnal (Al- irsyad, 2017)(Sutisna, 1989) menyatakan bahwa administrasi pendidikan hadir dalam tiga bidang perhatian dan kepentingan yaitu :

a. Setting Administrasi pendidikan (geografi, demograpi, ekonomi, ideologi, kebudayaan, dan pembangunan);

b. Pendidikan (bidang garapan Administrasi); dan

c. Substansi administrasi pendidikan (tugas-tugasnya, prosesnya, asas-asasnya, dan perilaku administrasi), hal ini makin

memperkuat bahwa manajemen/ administrasi pendidikan mempunyai bidang dengan cakupan luas yang saling berkaitan,

sehingga pemahaman tentangnya memerlukan wawasan yang luas serta antisipatif terhadap berbagai perubahan yang terjadi di masyarakat disamping pendalaman dari segi perkembangan teori dalam hal manajemen/administrasi.

(Afifuddin, 2005) Dalam kaitannya dengan makna manajemen/Administrasi Pendidikan berikut ini akan dikemukakan beberapa pengertian manajemen pendidikan yang dikemukakan para ahli. Dalam hubungan ini penulis mengambil pendapat yang mempersamakan antara Manajemen dan Administrasi terlepas dari kontroversi, sehingga kedua istilah itu dapat dipertukarkan dengan makna yang sama. Pendapat Pakar lainnya tentang Administrasi/ manajemenPendidikan:

a. Keseluruhan proses kerjasama dengan memanfaatkan semua sumber personil dan materil yang tersedia dan sesuai untuk mencapai tujuan pendidikan yang telah ditetapkan secara efektif dan efisien,yang merupakan arti dari Administrasi pendidikan (Djam'an Satori, 1980: 4).

b. Dalam pendidikan, manajemen itu dapat diartikan sebagai aktivitas memadukan sumber-sumber pendidikan agar terpusat dalam usaha mencapai tujuan pendidikan yang telah ditentukan sebelumnya (Made

Pidarta, 1988:4).

c. Educational administration is a social process that take place within the context of social system. (Castetter, 1996:198).

d. Manajemen pendidikan dapat di artikan

sebagaiprosesperencanaan,

pengorganisasian,memimpin,

mengendalikan tenaga pendidikan, sumber daya pendidikan untuk mencapai tujuan pendidikan (Soebagio Atmodiwirio, 2010: 23).

e. Manajemen pendidikan ialah suatu 
ilmu yang mempelajari bagaimana menata sumber daya untuk mencapai tujuan yang telah ditetapkan secara produktif dan bagaimana menciptakan suasana yang baik bagi manusia yang turut serta di dalam mencapai tujuan yang disepakati bersama. (Engkoswara, 2011).

2. Pentingnya administrasi pendidikan

(Sutisna, 2002) Sebagian orang beranggapan bahwa pendidikan berjalan dengan sendirinya, sehingga sering mengabaikan pentingnya administrasi di dalam menyelengarakan pendidikan atau istilah yang lebih dikenal adalah administrasi pendidikan.

Contoh ketika memasuki tahun ajaran baru maka sekolah akan membuat satu rencana yang berkaitan dengan penerimaan siswa baru. Misalnya dengan membentuk kepanitiaan,batas waktu penerimaan siswa baru, jumlah siswa yang akan diterima, apakah diterima dengan melakukan test tertulis atau cukup dengan menetapkan raport/hasil UAN.

3. Tujuan administrasi pendidikan

(Gunawan, 2002) Tujuan administrasi pendidikan adalah memberikan sistematika kerja dalam mengelola pendidikan. Sehingga tugas-tugas operasional kependidikan dapat dilaksanakan secara efektif dan efesien menuju sasaran atau tujuan yang telah ditetapan. Dengan demikian, para kepala sekolah dapat mengelola pendidikan dengan mudah dan menguasai bidang tugasnya.

(Sutisna, 2002) Setiap kegiatan di adakan proses administrasi pendidikan diarahkan untuk mencapai tujuan pendidikan. Adanya unsur tujuan ini

menimbulkan perlunya pengadministrasian pelaksanaan kurikulum yang menjadi tugas dan tanggung jawab kepala sekolah bersama guru-guru dan pegawai sekolah lainnya.

Tujuan administrasi pada umumnya adalah agar semua kegiatan mendukung tercapainya tujuan pendidikan atau dengan kata lain administrasi yang digunakan dalam dunia pendidikan diusahakan untuk mencapai tujuan pendidikan.

Sergiovanni dan Carver (1975 dalam

(Burhanuddin,
2005) menyebutkan empat tujuan administrasi:

1) Efektifitas produksi;

2) Efesiensi;

3) Kemampuan menyesuaikan diri (adaptivenes);

4) Kepuasan Kerja.

Keempat tujuan tersebut digunakan sebagai kriteria untuk menentukan keberhasilan dalam penyelenggaraan sekolah. Sebagai contoh: sekolah mempunyai fungsi untuk mencapai efektivitas produksi, yaitu menghasilkan lulusan yang sesuai dengan tuntutan kurikulum. Dalam pencapaian tujuan tersebut harus dilakukan usaha seefisien mungkin, yaitu menggunakan keperluan dana, dan tenaga seminimal mungkin, tetapi memberikan hasil sebaik mungkin, sehingga lulusan tersebut dapat melanjutkan ketingkat berikutnya dan dapat menyesuaikan dirinya dengan lingkunganya yang baru dan selanjutnya lulusan ini akan mencari kerja pada perusahaan yang memberikan kepuasan kerja kepada mereka.

\section{B. Fungsi/ proses administrasi pendidikan}

(Nawawi, 2003) Administrasi pendidikan tersebut juga mempunyai fungsi sebagai berikut:
1) Fungsi perencanaan merupakan sejumlah kegiatan yang ditentukan sebelumnya untuk dilaksanakan pada suatu periode tertentu guna mencapai tujuan yang telah ditetapkan.
2) Fungsi pengorganisasian, merupakan proses penentuan pekerjaan yang harus dilakukan pengelompokan tugas-tugas dan membagi-bagikan pekerjaan kepada setiap personalia.
3) Fungsi pelaksanaan merupakan usaha menggerakkan anggota kelompok sedemikian rupa sehingga mereka berkeinginan dan berusaha untuk mencapai sasaran organisasi. pemantauan, penilaian, dan pelaporan rencana atas pencapaian tujuan yang telah ditetapkan.
4) Fungsi pengawasan merupakan proses

(Prihatinin, 2011) Fungsi-fungsi pokok administrasi pendidikan

1) Perencanaan

Perencanaan merupakan kegiatan awal yang harus dilakukan pada permulaan dan selama kegiatan administrasi itu berlangsung dan merupakan salah satu 
syarat mutlak bagi setiap kegiatan administrasi. Tanpa perencanaan, pelaksanaan suatu kegiatan akan mengalami kegagalan dan kesulitan dalam mencapai tujuan. Di setiap perencanaan ada dua faktor sarana, baik sarana material maupun personel. Langkah-langakah dalam perencanaan meliputi hal-hal sebagai berikut:

a. Merumuskan dan Menentukan tujuan yang ingin dicapai

b. Meneliti masalah atau pekerjaan yang akan dilakukan

c. Data dan informasi-informasi yang diperlukan harus di cari dan dikumpulkan

d. Menentukan tahap-tahap atau rangkaian tindakan

e. Merumuskan bagaimana pekerjaan itu akan diselesaikan dan bagaimana masalah-masalah itu akan dipecahkan.

2) Pengorganisasian

Pengorganisasian sebagai fungsi administrasi pendidikan menjadi tugas utama bagi para pemimpin pendidikan termasuk kepala sekolah .Yang perlu diperhatikan dalam pengorganisasian antara lain ialah bahwa pembagian tugas, wewenang, dan taggung jawab, hendaknya disesuaikan dengan pengalaman, bakat, minat, pengetahuan, dan kepribadian masing-masing orang yang yang diperlukan dalam menjalankan tugas-tugas tersebut. Fungsi organisasi dapat diartikan berrmacam-macam

a. Organisasi dapat diartikan sebahai memberi struktur, terutama dalam penyusunan/ penempatan personal, pekerjaan-pekerjaan, material, dan pikiran di dalam struktur itu.

b. Organisasi dapat pula ditafsirkan sebagai menetapkan hubungan antara orang-orang, kewajiban, hak, dan tanggung jawab masing-masing anggota disusun menjadi pola-pola kegiatan yang tertuju pada pencapaian tujuan atau maksud kegiatan pendidikan dan pengajaran

c. Organisasi dapat pula diartikan semata-mata mengingat maksudnya, yakni sebagai alat untuk mempersatukan usaha-usaha untuk menyelesaikan pekerjaan.

3) Pengkoordinasian

Adanya bermacam-macam tugas atau pekerjaan yang dilakukan oleh banyak orang, memerlukan adanya koordinasi yang baik dapat mengindari kemungkinan terjadinya persaingan yang tidak sehat dan kesimpangsiuran dalam tindakan. Dengan adanaya koordinasi yang baik, semua bagian dan personel dapat bekerja sama menuju ke satu arah tujuan yang telah ditetapkan. Koordinasi ini perlu untuk mengatasi batas-batas perencanaan maupun batas-batas personel seperti untuk mengatasi kemungkinan adanya duplikasi dalam tugas,

perebutanhakdantanggungjawab,

ketidakseimbangan dalam berat-ringannya pekerjaan, kesimpangsiuran dalam menjalankan tugas dan kewajiban.

4) Pengkomunikasian

Yaitu suatu proses yang hendak mempengaruhi sikap dan perbuatan orang-orang dalam struktur organisasi. Di dalam kegiatan komunikasi diperlukan adanya motivasi, terutama motivasi intrinsik. Oleh karena itu, pemberian motivasi dalam rangka

komunkasi hendaknya memperhatikan beberapa unsur seperti berikut ;

a. Adanya keinginan untuk berhasil

b. Kejelasan tentang tindakan yang harus diambil/dianjurkan

c. Keyakinan bahwa perubahan yang dianjurkan akan membawa hasil positif

d. Keyakinan akan adanya kesempatan yang sama bagi semua anggota

e. Keyakinan akan adanya kebebasan untuk menentukan, menolak, ataupun menerima ap a yang dianjurkan

5) Supervisi

Dalam pelaksanaan program pendidikan tentu harus disertai dengan adanya pengawasan dan pembinaan. Pembinaan itu berupa tuntunan atau bimbingan ke arah situasi pendidikan pada perbaikan umumnya. Proses pengawasan program pendidikan harus dilakukan dengan teliti agar tujuan pendidikan dapat tercapai.

6) Kepegawaian

Kepegawaian merupakan dari proses perencanaan dan pengorganisasian yang sudah di mulai di dunia pendidikan. kepegawaian yang di angkat harus memiliki kesanggupan dan kecakapan yang sesuai 
dengan jabatan diembatnya. Sehingga, administrasi pendidikan dapat diupayakan jabatan yang akan diduduki itu adalah mereka yang punya kemampuan dan kapabilitas sesuai dengan jabatan yang diberikan dan bertanggung jawab.

7) Pembiayaan

Yaitu proses biaya pendidikan dengan pengelolaannya mulai dari tingkat perencanaan sampai ke tingkat pada pengukuran efisiensi, sehingga perencanaan administrasi pendidikan. Kebutuhan di setiap organisasi, baik personel maupun material, semuanya memerlukan biaya tertentu. Itulah sebabnya pembuatan planning sampai dengan pelaksanaan perlu kita fikirkan soal

pembiayaanya. Dalam pembiayaan ada

beberapa hal yang perlu diperhatikan dalam fungsinya,yaitu :

a. Perencanaan tentang beberapa biaya yang diperlukan

b. Darimana dan bagaimana biaya itu dapat diperoleh/diusahakan

c. Bagaimana pengunaanya

d. Siapa yang akan melaksanakan

e. Bagaimana pembukuan dan pertanggungjawaban

f. Bagaimana pengawasan, dll

8) Penilaian

Bertujuan untuk meneliti dan mengetahui efektivitas pelaksanaan proses keseluruhan organisasi dalam upaya pencapaian hasil sesuai program yang ditetapkan dalam kaitannya untuk pencapaian tujuan pendidikan. Jadi kegiatan evaluasi sangat diperlukan.

Setiap kegiatan, baik yang dilakukan oleh unsur pimpinan maupun oleh bawahan, memerlukan adanya evaluasi. Dengan diketahui kesalahan atau kekurangan serta kemacetan yang diperoleh dari tindakan evaluasi itu selanjutnya dapat diusahakan bagaimana cara-cara memperbaikinya.

\section{Ruang lingkup administrasi pendidikan}

Menurut (Prihatinin, 2011) Lembaga pendidikan seperti organisasi sekolah merupakan kerangka kelembagaan dimana administrasi pendidikan dapat berperan dalam mengelola organisasi untuk mencapai tujuan yang telah ditetapkan. Dilihat dari tingkatan-tingkatan suatu organisasi dalam sekolah, administrasi pendidikan dapat dilihat dalam tiga tingkatan yaitu tingkatan institusi (instutional level). Tingkatan manajerial (manajerial level), dan tingkatan teknis (technical level) (murphy dan louis, 1999). Tingkatan institusi berkaitan dengan hubungan antara lembaga pendidikan (sekolah) dengan lingkungan eksternal, tingkatan manajerial berkaitan dengan kepemimpinan, dan orgasnisasi lembaga sekolah (sekolah). Dan tingkatan teknis berkaitan dengan proses pembelajaran. Dengan demikian manajemen pendidikan dalam konteks kelembagaan pendidikana mempuntai cakupan yang luas, disamping itu bidang-bidang yang harus ditanganinya juga cukup banyak dan kompleks dari mulai sumber daya fisik, keuangan, dan manusia yang terlibat dalam kegiatan proses pendidikan di sekolah.

Consurtium on renewing education berpendapat sekolah (lembaga pendidikan) mempunyai lima bentuk modal yang perlu dikelola untuk keberrhasilan pendidikan yaitu :
a) Integrative capital
b) Human capital
c) Financial capital
d) Social capital
e) Political capital

Modal intefratif adalah modal yang dengan pengintegrasial empay modal lainnya untuk dapat dimanfaatkan bagi pencapaian program/tujuan pendidikan. Modal manusia adalah sumberrdaya manusia yang kemampuan untuk menggunakan pengetahuan bagi kepentingan proses pendidikan/ pembelajaran, model keuangan adalah dana yang diperlukan untuk menjalankan dan memperbaiki proses pendidikam, model sosial adalah ikatan keperccyaan dan kebiasaan yang menggambarkan sekolah sebagai komunitas, dan modal politik adalah dasar otoritas legal yang dimiliki untuk melakukan proses pendidikan/pembelajaran.

Ruang lingkup Menurut (Daryanto, 2011)Bidang-bidang yang tercakup dalam administrasi pendidikan adalah sangat banyak dan luas. Tetapi yang sangat penting dan perlu diketahui oleh para kepala sekolah dan guru-guru pada umumnya ialah sebagai berikut:

\footnotetext{
A. Bidang tata usaha sekolah, ini meliputi :
} 
1. Organisasi dan struktur pegawai tata usaha

2. Anggaran belanja keuangan sekolah

3. Masalah kepegawaian dan personalia sekolah

4. Keuangan dan pembukuannya

5. Koresponden/surat menyurat

6. Masalah pengangkatan, pemindahan, penempatan, laporan, pengisian buku induk, raport, dan sebagainya.

B. Bidang personalia murid, yang mmeliputi antara lain:

1. Organisasi murid

2. Masalah kesehatan murid

3. Masalah kesejahteraan muridEvaluasi kemajuan murid

4. Bimbingan dan penyuluhan bagi murid

C. Bidang personalia guru, meliputi antara lain:

1. Pengangkayan dan penempatan tenaga guru

2. Organisasi personel guru

3. Masalah kepegawaian

4. Masalah kindite dan evaluasi kemajuan guru

5. Refreshing dan up-grading guru-guru

D. Bidang pengawasan (supervisi), yang meliputi atara lain

1. Upaya meningkatkan semangat guru dan pegawai tata usaha.

2. Mengupayakan dan mengembangkan kerjasama yang baik antara guru, murid, dan pegawai tata usaha sekolah.

3. Mengupayakan dan membuat pedoman cara-cara menilai hasil-hasil pendidikan dan pengajaran.

4. Upaya untuk meningkatkan mutu dan pengalaman guru

E. Bidang pelaksanaan dan pembinaan kurikulum

1. Berpedoman dan mengetrapkan apa yang tercantum dalam kurikulum sekolah yang bersangkutan, dalam usaha mencapai dasar-dasar dan tujuan pendidikan dan pengajaran

2. Melaksanakan organisasi kurikulum beserta metode-metodenya, disesuaikan dengan pembaruan oendidikan dan lingkungan masyarakat.

\section{Kesimpulan}

Administrasi pendidikan adalah segenap teknik dan prosedur yang digunakan dalam penyelenggaraan hubungan pendidikan sesuai dengan kebijakan yang telah ditetapkan guna untuk mencapai tujuan pendidikan. Dalam rangka operasionalisasi konsep adminitrasi pendidikan tersebut, Sekolah sebagai organisasi pendidikan harus mengelola tiga hal yakni material, SDM dan kurikulum. Proses dari administrasi pendidikan terdiri dari Perencanaan, pengorganisasian, pelaksanaan, dan pengawasan. Administrasi yang baik dan teratur akan membuat jalannya pendidikan dan tujuan pendidikan tercapai secara efektif dan efesien.

\section{Daftar Pustaka}

Afifuddin, D. (2005). administrasi pendidikan. Bandung: CV. Intan Mandiri.

Afriansyah, H. (2019). Administrasi Peserta

Didik. Padang. https://doi.org/10.17605/OSF.IO/NRXH8.

Asnawir. (2005). Administrasi Pendidikan. Padang: IAIN IB Press.

Al-irsyad. (2017). Kajian administrasi pendidikan di dunia pendidikan. JURNAL AL-IRSYAD, Vol. VIII, .

Burhanuddin. (2005). Administrasi

Pendidikan. Bandung:

Pustaka Setia.

Daryanto. (2011). Administrasi pendidikan. Jakarta: Rineka cipta.

Engkoswara. (2011). Administrasi Pendidikan. bandung: Alfabeta.

Gunawan. (2002). AdministrasiSekolah (administrasi

pendidikan mikro). Jakarta: Rineka cipta.

Hadjaya, Y. (2012). Administrasi pendidikan.

Medan: Perdana Publishing.

Kamars, D. (2004). Administrasi Pendidikan

Teori dan Praktek. Padang: Suryadi Indah.

Nawawi, H. (2003). Administrasi pendidikan.

Jakarta: gunung agung.

Prihatinin,E. (2011). Teori Administrasi 
Pendidikan.

bandung: ALFABETA.

Sutisna. (2002). Perilaku konsumen dan

komunikasi pemasaran. bandung: Rineka cipta.

Sutisna,O. (1989). Administrasi

pendidikan.Bandung:

Angkasa. 




